number to 96 ; and I would desire, consequently, to record it as follows :-

\title{
Cydonia vicina.
}

Cheilomenes vicina, Dej., Cat. 459 (1837).

- circumflexa (Klug), Id., ibid. (1837).

Cydonia vicina, Muls., Sécurip. 440 (1851).

_ —, Woll., Col. Hesp. 155 (1867).

$H a b$. Sanctam Helenam, teste cl. G. R. Crotch.

I have likewise a note from $\mathrm{Mr}$. Crotch to the effect that the Spharidium dytiscoides of Fabricius is still preserved in the Banksian collection, and that a friend of his who has recently examined it reports it to be totally distinct from the Dactylosternum abdominale, being, in point of fact (as, indeed, I had ventured to think probable), a true Cyclonotum, and one which occurs also at the Cape of Good Hope.

XIV.-On the Anatomy of the Nervous System of Diphyes, affording presumptive evidence of the existence of a similar System in the other forms of Oceanic Hydrozoa. By JoHn Denis Macdonald, M.D., F.R.S., Staff-Surgeon of H.M.S. 'Lord Warden.' *

While cruising off the coast of Portugal, a few hauls of the towing-net brought up many specimens of a species of Diphyes which I have not determined, as the suitable books were not at hand; this, however, may be readily done by referring to the figure accompanying this paper. I very carefully examined several of these animals (or, I am rather tempted to say, animal forms) in relation to the received views of the structure and organization of the group to which they belong. In some instances the two nectocalyces were nearly intact, while in others they were separated, which is more usually the case. This latter remark is also quite true of the parts of numerous other oceanic Hydrozoa, which were quite problematical to most students of zoology until Professor Huxley elucidated their structure by independent research, which enabled him also to render the results obtained by others more intelligible.

In the present species the proximal nectocalyx is about twice as large as the distal one, sharp-pointed, three-sided, and much laterally compressed at the free extremity, but distinctly quadrilateral at the base, where two angular pro-

* Communicated by the Director-General of the Medical Department of the Navy. 
cesses, with curtain-like flaps between them, bound the polypecell, including the apex of the distal nectocalyx. This latter is also four-sided and laterally compressed, bearing the propulsive chamber or nectosac above, and a deep longitudinal groove for the chaplet of polypes beneath, while the free extremity terminates in a double-pointed projection. All the angles and edges of both nectocalyces are faintly serrated, with the points directed towards the base in each, so as to offer little or no resistance to the water during natation. The figure will give a sufficient idea of the general characters of this species, without further description, except what is to be said of the nervous system, the exposition of which is the principal object of this paper.

At the base of the polype-cell, just within the attachment of the conosare, and above the duct of the somatocyst, there appeared to me to be a little ganglionic mass; but of this I cannot be quite certain until I investigate the matter a little more closely. I am satisfied, however, that I have been able to trace a nerve-trunk from that point along the inferior wall of the polype-cell to the angle between it and the open end of the nectosac, the upper wall of which is supplied with two long and tapering nerves, bifurcating from the primary trunk. A second principal nerve was distinctly traceable into the

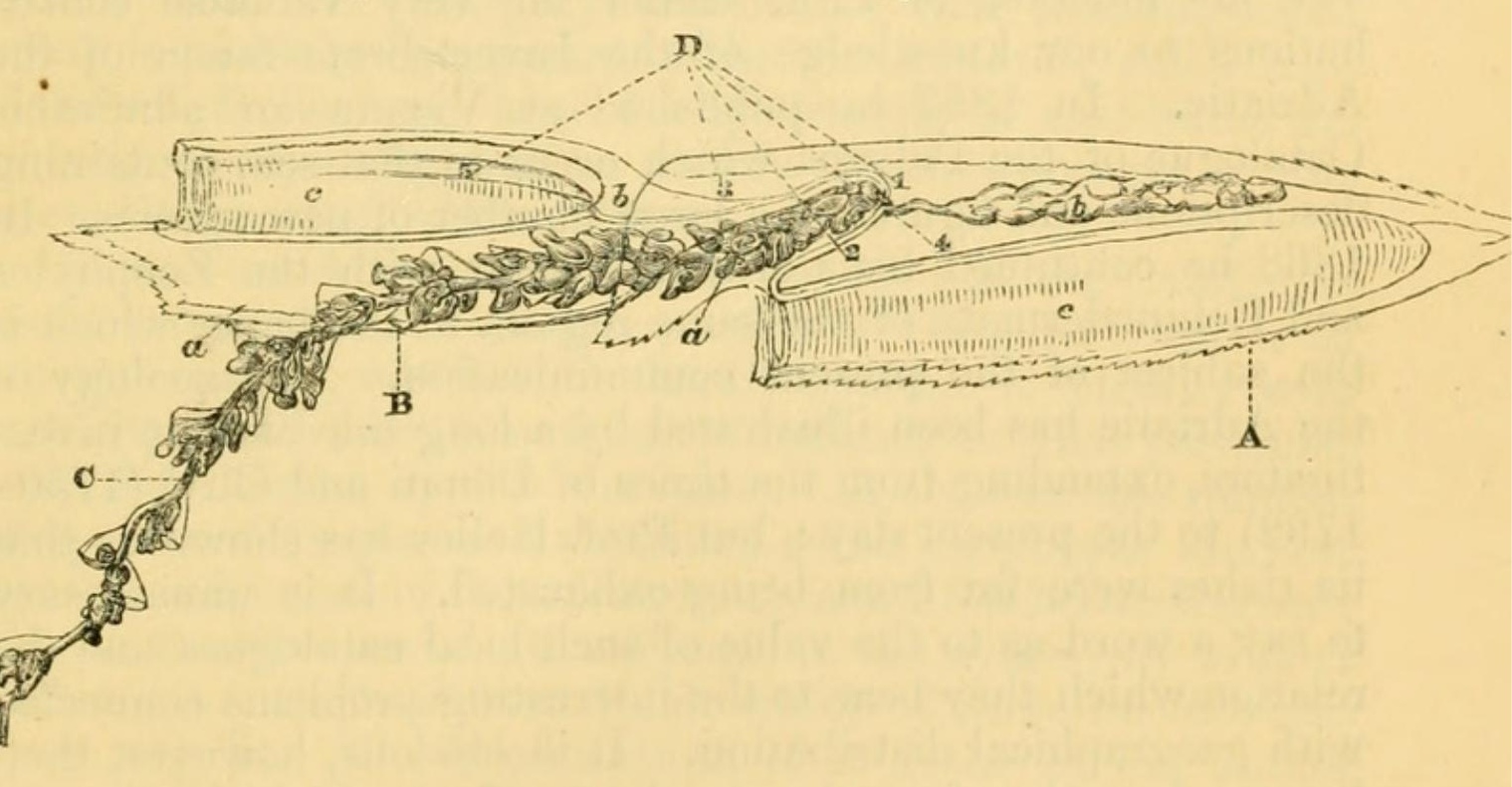

A, the proximal nectocalyx: $a$, polype-cell, lodging the cœnosarc and polypes; $b$, somatocyst, communicating with the cœnosare cavity; $c$, nectosac or propulsive chamber.

$\mathrm{B}$, the distal nectocalyx : $a$, protective groove for the polypes; $b$, pedicel of the nectosac including the nerve; $c$, the nectosac.

$\mathrm{C}$, chaplet of coenosarc and polypes.

$\mathrm{D}$, the nervous system: 1 , nervous centre?; 2, proximal nerve-trunk; 3 , distal nerve-trunk; 4 , branches to proximal nectosac; 5 , branches to distal nectosac. 
apex of the distal nectocalyx; and having run along the polype-groove as far as the fundus of the nectosac, where it was surrounded by a tubular process of endoderm, it also terminated in a bifurcation, the resulting branches being distributed to the upper wall of the sac, as in the former case.

Though the movements of Diphyes are very variable, the normal position is that in which the chaplet of polypes trails from the groove of the distal nectocalyx, the nectosac being superior or on the neural side.

The nectosacs give propulsion to the whole organism, with the pointed extremity of the proximal nectocalyx foremost; nevertheless I am disposed to think that the movement is truly retrograde, as in the case of the cuttlefishes; and if this be true, all the terms of relation used in the description of animals having a bilateral symmetry will be applicable to Diphyes.

H.M.S. 'Lord Warden.'

Gibraltar, Oct. 10, 1871.

XV.-Note on Prof. Heller's Catalogue of the Hydroida of the Adriatic*. By the Rev. Thomas Hincks, B.A.

WE are indebted to Prof. Heller for very valuable contributions to our knowledge of the Invertebrate fauna of the Adriatic. In 1867 he published at Vienna an admirable Catalogue of the Polyzoa which occur in that sea, containing descriptions and figures of a large number of new species. In 1868 he continued his work, and dealt with the Zoophytes and Echinodermata of the same region, in the paper which is the subject of the present communication. The zoology of the Adriatic has been illustrated by a long line of able investigators, extending from the times of Donati and Olivi (1750$1792)$ to the present day; but Prof. Heller has shown us that its riches were far from being exhausted. It is unnecessary to say a word as to the value of such local catalogues and the relation which they bear to the interesting problems connected with geographical distribution. It is obvious, however, that, inasmuch as they form the storehouses from which the theorist draws his facts, it is of the first importance that they should be characterized by rigorous accuracy in the discrimination and identification of species. In that portion of his work which relates to the Hydroida, Prof. Heller has needlessly increased the chances of error, has rendered, indeed, a certain amount of

* "Die Zoophyten und Echinodermen des Adriatischen Meeres, von Prof. Cam. Heller in Innsbruck," 1868. 


\section{$2 \mathrm{BHL}$ Biodiversity Heritage Library}

Macdonald, John Denis. 1872. "XIV.-On the anatomy of the nervous system of Diphyes, affording presumptive evidence of the existence of a similar system in the other forms of oceanic Hydrozoa." The Annals and magazine of natural history; zoology, botany, and geology 9, 114-116.

https://doi.org/10.1080/00222937208696550.

View This Item Online: https://www.biodiversitylibrary.org/item/54555

DOI: https://doi.org/10.1080/00222937208696550

Permalink: https://www.biodiversitylibrary.org/partpdf/53771

\section{Holding Institution}

Smithsonian Libraries

\section{Sponsored by}

Smithsonian

\section{Copyright \& Reuse}

Copyright Status: Public domain. The BHL considers that this work is no longer under copyright protection.

This document was created from content at the Biodiversity Heritage Library, the world's largest open access digital library for biodiversity literature and archives. Visit BHL at https://www.biodiversitylibrary.org. 